University of Nebraska - Lincoln

DigitalCommons@University of Nebraska - Lincoln

\title{
Transport of multiple tracers in variably saturated humid region structured soils and semi-arid region laminated sediments
}

\author{
M.A. Mayes \\ Oak Ridge National Laboratory, mayesma@ornl.gov \\ P.M. Jardine \\ Oak Ridge National Laboratory \\ T.L. Mehlhorn \\ Oak Ridge National Laboratory \\ B.N. Bjornstad \\ Pacific Northwest National Laboratory \\ J.L. Ladd \\ Tennessee Technological University \\ See next page for additional authors
}

Follow this and additional works at: https://digitalcommons.unl.edu/usdoepub

Part of the Bioresource and Agricultural Engineering Commons

Mayes, M.A.; Jardine, P.M.; Mehlhorn, T.L.; Bjornstad, B.N.; Ladd, J.L.; and Zachara, John M., "Transport of multiple tracers in variably saturated humid region structured soils and semi-arid region laminated sediments" (2003). US Department of Energy Publications. 275.

https://digitalcommons.unl.edu/usdoepub/275

This Article is brought to you for free and open access by the U.S. Department of Energy at DigitalCommons@University of Nebraska - Lincoln. It has been accepted for inclusion in US Department of Energy Publications by an authorized administrator of DigitalCommons@University of Nebraska - Lincoln. 


\section{Authors}

M.A. Mayes, P.M. Jardine, T.L. Mehlhorn, B.N. Bjornstad, J.L. Ladd, and John M. Zachara 


\title{
Transport of multiple tracers in variably saturated humid region structured soils and semi-arid region laminated sediments
}

\author{
M.A. Mayes ${ }^{\mathrm{a}, *}$, P.M. Jardine ${ }^{\mathrm{a}}$, T.L. Mehlhorn ${ }^{\mathrm{a}}$, B.N. Bjornstad ${ }^{\mathrm{b}}$, J.L. Ladd ${ }^{\mathrm{c}}$, \\ J.M. Zachara ${ }^{\mathrm{b}}$ \\ ${ }^{a}$ Environmental Sciences Division, Oak Ridge National Laboratory, P.O. Box 2008, Oak Ridge, TN 37831-6038, USA \\ ${ }^{\mathrm{b}}$ Pacific Northwest National Laboratory, P.O. Box 999, Richland, WA 99352, USA \\ ${ }^{\mathrm{c}}$ P.O. Box 5013, Tennessee Technological University, Cookeville, TN 38505, USA
}

Received 21 March 2001; accepted 17 January 2003

\begin{abstract}
The processes governing physical nonequilibrium (PNE) — coupled preferential flow and matrix diffusion-are diverse between humid and semi-arid regions, and are directly related to climate and rock/sediment type, and indirectly related to subsequent soil profile development. The fate and transport of contaminants in these variably saturated undisturbed media is largely a function of the influence of PNE processes. Large cores of laminated silts and sands were collected from the US Department of Energy Pacific Northwest National Laboratory (PNNL) in semi-arid south central Washington. Additional cores of weathered, fractured interbedded limestone and shale saprolite were collected from the Oak Ridge National Laboratory (ORNL) in humid eastern Tennessee. PNNL cores were collected parallel (FBP) and perpendicular (FXB) to bedding, and the ORNL core was $30^{\circ}$ to bedding. Saturated and unsaturated transport experiments were performed using multiple nonreactive tracers that had different diffusion coefficients ( $\mathrm{Br}^{-}$, PFBA, and PIPES), in order to identify the influence of PNE on the fate and transport of solutes. In the ORNL structured saprolite, solute transport was governed by coupled preferential flow and matrix diffusion, as evidenced by tracer separation and highly asymmetric breakthrough curves (BTC). BTCs became more symmetric as preferential flowpaths became inactive during drainage. Tracer separation persisted during unsaturated flow suggesting the continued importance of nonequilibrium mass transfer between flowpaths and the immobile water that was held in the soil matrix. No evidence of PNE was observed under near-saturated conditions in the semi-arid region (PNNL) laminated silts and sands. Unsaturated flow in cores with discontinuous layering resulted in preferential flow and the development of perched, immobile water as evidenced by early breakthrough and separation of tracers. Conversely, transport parallel to laterally continuous beds did not result in preferential flow, the development of perched water, or tracer separation regardless of water content. These observations suggested that desaturation had two effects: (1) grain size variations between individual beds resulted in different antecedent water contents, and (2) the exchange of water and solutes between individual sedimentary beds was subsequently inhibited. Under unsaturated conditions, these effects may promote either stable lateral flow, or unstable vertical finger flow coupled with the development of perched, immobile water.
\end{abstract}

(C) 2003 Elsevier Science B.V. All rights reserved.

Keywords: Unsaturated zone; Preferential flow; Diffusion; Equilibrium; Breakthrough curves

\footnotetext{
* Corresponding author. Tel.: +1-865-574-7336; fax: + 1-865-576-8646.

E-mail address: mayesma@ornl.gov (M.A. Mayes).
}

0022-1694/03/\$ - see front matter (C) 2003 Elsevier Science B.V. All rights reserved. doi:10.1016/S0022-1694(03)00039-8

This article is a U.S. government work, and is not subject to copyright in the United States. 


\section{Introduction}

A primary control upon groundwater quality is the capacity of the vadose zone in transmitting water and/or contaminants to greater depths. At two US Department of Energy sites, the Hanford Reservation in south-central Washington and the Oak Ridge Reservation in eastern Tennessee, the subsurface burial of contaminants within the unsaturated zone has generally been unsuccessful at quarantining radioactive metals and organic wastes (Looney and Falta, 2000; Olsen et al., 1986). At ORNL, a fractured shale/limestone saprolite has developed in the high precipitation regime. Contaminant transport occurs by rapid preferential flow along fractures and bedding planes, while rate-limited diffusional exchange with the matrix results in the slow release of contaminants over long time periods (Jardine et al., 2001). The high density of interconnected fractures results in rapid vertical flow along pathways dictated by macroscopic geologic features (e.g. topography, subsurface bedding planes). Conversely, at Hanford, young unconsolidated sediments comprise a deep vadose zone $(100 \mathrm{~m})$ in this semi-arid region. The vertical movement of water and solutes in dry sands may be impeded by fine scale textural differences between sediment layers, resulting in local-scale perched water and lateral flow. Textural differences can promote the development of an unstable wetting front, which is characterized by rapid finger flow separated by drier regions of immobile water (Glass et al., 1988, 1989; Hillel and Baker, 1988; Ritsema et al., 1993, 1998; DiCarlo et al., 1999; Bauters et al., 2000; Sililo and Tellam, 2000). In addition, funneling along lithologic heterogeneities, such as faults, clastic dikes, or boreholes may concentrate flow to deeper regions. Thus, in both humid and semi-arid climatic regimes, preferential flow may result in accelerated contaminant transport to depth and/or sequestration into relatively immobile regions.

The technique of multiple nonreactive tracers has been used to identify the contributions of preferential flow and matrix diffusion in structured media (Jardine et al., 1998, 2001; Langner et al., 1999; Becker and Shapiro, 2000; Moline et al., 2001). In miscible displacement through undisturbed structured soils, asymmetric breakthrough curves (BTC) are obtained under saturated conditions because of the combination of rapid fracture flow and slow matrix diffusion (Seyfried and Rao, 1987; Jardine et al., 1988, 1993; Langner et al., 1999). Curve asymmetry is pronounced at higher velocities due to greater proportions of advective preferential flow and decreasing contributions of matrix diffusion (Smettem, 1984; Koch and Fluhler, 1993; Gaber et al., 1995; Becker and Shapiro, 2000). With decreasing saturation, however, an increasingly symmetric BTC is obtained as larger pores become inactive during drainage, because flow is restricted to a more homogenous set of smaller pores (Seyfried and Rao, 1987; Jardine et al., 1993; Gaber et al., 1995; Langner et al., 1999). Combination of the techniques of multiple tracers and multiple pressure heads provides an opportunity to resolve nonequilibrium processes in the vadose zone (e.g. Langner et al., 1999).

Few displacement experiments have been performed on undisturbed sediments from semi-arid regions, and none have successfully utilized multiple nonreactive tracers. Typically, single or nontracer steady-state or transient experimental techniques have been utilized to understand water flow in semi-arid region sediments. These are often employed in repacked columns of unsaturated silts and sands (e.g. Bond and Wierenga, 1990; Porro and Wierenga, 1993; Padilla et al., 1999; Gamerdinger and Kaplan, 2000). Steady-state transport in repacked silts and sands yields symmetric BTC during saturated conditions and asymmetric BTC under unsaturated conditions, which contrasts with BTCs observed in structured soils. Further, decreasing the water content usually results in higher proportions of immobile water (Padilla et al., 1999; Gamerdinger and Kaplan, 2000), though immobile water has also been observed under saturated conditions (Bond and Wierenga, 1990). Transient flow experiments are also common for investigating water and solute movement into initially dry semi-arid subsurface media, resulting in water content and matric potential which are a function of time and distance into the media. Many laboratory and field studies have observed an unstable wetting front and preferential finger flow during infiltration into dry sediments (Glass et al., 1988, 1989; Ritsema et al., 1993, 1998; Bauters et al., 2000; DiCarlo et al., 1999; Sililo and Tellam, 2000), though some have not (Diment and Watson, 1985; Young et al., 1999). Nearly identical BTC have been obtained 
for transient and steady-state conditions (Porro and Wierenga, 1993), which suggests the same processes may govern transport in disturbed sandy media regardless of antecedent water content. The rate of exchange between the mobile and immobile regions, however, has only been identified by fitting BTCs for single species $\left(\mathrm{Br}^{-}, \mathrm{Cl}^{-}\right.$, or $\left.\mathrm{H}_{3} \mathrm{O}\right)$ (e.g. Bond and Wierenga, 1990; Porro and Wierenga, 1993; Padilla et al., 1999; Gamerdinger and Kaplan, 2000). The combination of the transport of multiple tracers at variable pressure heads has not been completed in sandy/silty media from semi-arid regions.

The objective of this study is to compare the transport of multiple nonreactive tracers through variably saturated undisturbed structured cores from a humid region and laminated sediment cores from a semi-arid climatic regime. The importance of preferential flow, matrix diffusion, and the formation of immobile water will be identified using multiple nonreactive tracers with different diffusion coefficients. The effect of variable water content upon transport will be determined by performing saturated and progressively unsaturated transport experiments within each core. In addition, the effect of lateral versus vertical flow will be compared in horizontal and vertical cores in the stratified semi-arid region sediments. Our goal is to provide an improved understanding of the key hydrologic processes that control contaminant transport in heterogeneous subsurface environments. This paper extends previous work completed on select structured soils to vastly different semi-arid region laminated sediments.

\section{Materials and methods}

\subsection{Collection of undisturbed cores}

The humid region cores were retrieved from the Melton Branch Watershed within the Oak Ridge National Laboratory (ORNL) in Oak Ridge, TN. This material is predominantly fractured shale saprolite (Fig. 1a), from the Cambrian age Conasauga Group, a heterogeneous formation of interbedded shales, limestones and silts that has been folded and faulted during the Alleghenian orogeny (Hatcher et al., 1992). The Dismal Gap Formation (within the uppermost Conasauga) is characterized as an acidic Inceptisol. The formation has been subjected to intense weathering in the humid climate of eastern Tennessee, where average precipitation exceeds $1500 \mathrm{~mm} \mathrm{yr}^{-1}$. Rainfall infiltration occurs along bedding planes and fractures (Fig. 1a), which have been determined to exceed 200 fractures $\mathrm{m}^{-1}$ (Dreier et al., 1987). Fe and Mn-oxides, in addition to translocated clays, coat many fractures and bedding planes. Most of the porosity, which averages $40-50 \%$, resides within the fine-grained matrix blocks with dimensions on the $\mathrm{cm}$ scale (Rothschild et al., 1984). These soil types are identical to those used in the disposal of radioactive waste on the Oak Ridge Reservation.

Undisturbed cores of the fractured saprolite were collected by a hand-sculpting method (Jardine et al., 1993; Reedy et al., 1996), which entails isolating a small pedon, coating with paraffin wax, and meticulously carving the sample to its finished dimensions (17.4 cm diameter $\times 40 \mathrm{~cm}$ length). This technique is a necessity to preserve the network of fractures and bedding planes that have developed in this media. One vertical column was excavated from a ridgetop location that had an approximate bedding plane dip of $30^{\circ}$. Therefore flow through the column would be expected to occur both along bedding planes and through numerous cross-cutting fractures (Fig. 1a). Two additional undisturbed cores $(8.6 \mathrm{~cm}$ diameter $\times 6 \mathrm{~cm}$ length) were collected for the purposes of determining the moisture retention function (MRF), by driving brass sleeves into the soil using a hammer-driven core sampler (Klute, 1986).

The semi-arid region media was retrieved from the White Bluffs above the Columbia River near the Pacific Northwest National Laboratory (PNNL) in Richland, WA. The sediments consist of laminated silts and sands derived from the Miocene-Pliocene age Upper Ringold Formation. This heterogeneous, unconsolidated formation was deposited within a lacustrine environment in the Pasco Basin in southcentral Washington (Lindsey and Gaylord, 1990). These materials are similar to sediments residing beneath the Hanford Reservation tank farms where large inventories of radionuclides have leaked into the vadose zone. The vadose zone in the vicinity of the Hanford Reservation is approximately $100 \mathrm{~m}$ thick, with the Upper Ringold formation encompassing 

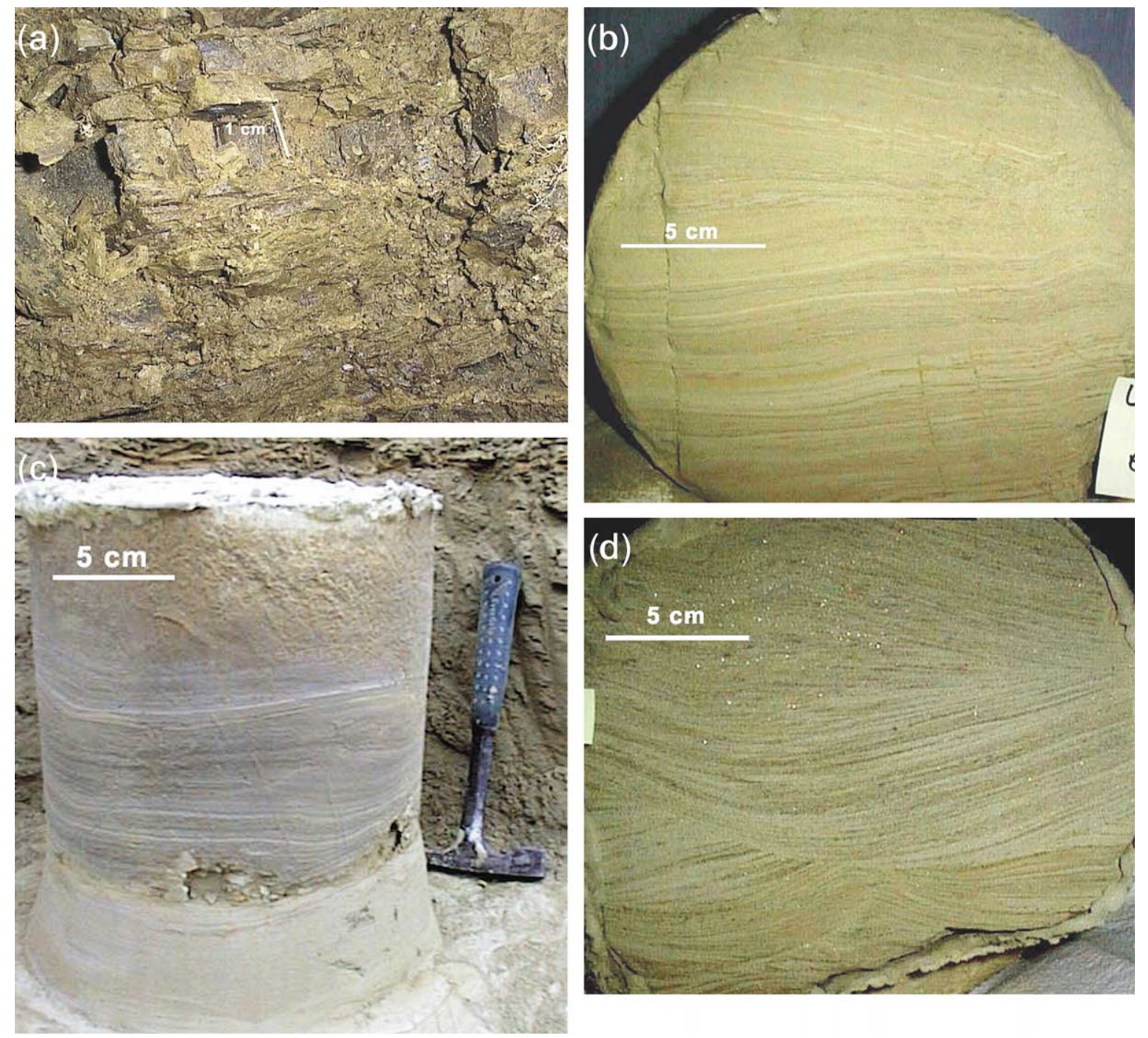

Fig. 1. Examples of each undisturbed media. (a) ORNL Conasauga Group saprolite from ridgetop exposure in the Melton Branch Watershed, Oak Ridge, TN. Note the numerous oxide-coated bedding planes and cross-cutting fractures. (b) PNNL Upper Ringold Formation from White Bluffs, Richland, WA. Upper Silt/Sand unit (US) flow bedding parallel (FBP) core. The core was composed of three units, a horizontal silt, overlain by two depositional units of sandy, silty material. Note Fe-oxide staining on bedding planes (cm-to mm-scale). Note also several fractures, and resultant offset of bedding planes. (c) PNNL Upper Ringold Formation, Upper Silt/Sand unit (US) flow bedding perpendicular (FXB) core. (d) PNNL Upper Ringold formation, Lower Sand/Silt (LS/S) flow bedding parallel (FBP) core. The core was composed of 4-5 units of sandy, silty material. Erosional downcutting identified each successive layer.

the lower one-third. Annual rainfall in the region averages $170 \mathrm{~mm} \mathrm{yr}^{-1}$. The Upper Ringold consists of horizontal silts indicative of quiet lakebed conditions, and cross-bedded, rippled sandier layers which are indicative of storm-influenced deposits (Bjornstad, 1990). Prominent deposits of Fe-oxides coat the surfaces of most bedding planes (Fig. 1b-d) Two units within the upper Ringold were sampled, which were separated in the field by $25 \mathrm{~cm}$ of horizontally bedded silt. The upper unit consisted of horizontal silts overlain by two rippled, currentinfluenced deposits with increased sand and mica 
content (Fig. 1b and c). Particle size analysis indicated this upper unit was $42.0 \%$ sand, $56.3 \%$ silt, and $1.7 \%$ clay, as determined by the bouycous hydrometer method (Klute, 1986). This will be referred to hereafter as the 'Upper silt/sand unit' (US), while the lower unit will be referred to as the 'Lower sand/ silt unit' (LS/S). The lower unit consisted entirely of current-influenced deposits, and was characterized by cross-bedded micaceous sandy layers which downcut into the lower layers (Fig. 1d). At least five separate depositional units were represented within the LS/S. Particle size analysis indicated the LS/S contained $57.0 \%$ sand, $42.2 \%$ silts, and $0.8 \%$ clay. Complete mineralogical characterization of both units in the U. Ringold formation is available in Roh et al. (2003).

Undisturbed cores of the laminated silts and sands were collected from freshly prepared escarpments on a roadcut using an air-purged rotary coring apparatus which was mounted onto a backhoe bucket. The hydraulics of the backhoe bucket allowed for the collection of cores at any angle. Two horizontal cores and one vertical core measuring $\sim 0.03 \mathrm{~m}$ diameter $\times \sim 0.03 \mathrm{~m}$ length (Table 1 ) were collected from each upper and lower unit within the U. Ringold (total of six cores). Expandable foam was used to fill the annulus during coring, allowed to harden, and the surrounding material was excavated to provide an encased core with open ends at the column boundaries. Four small, undisturbed cores $(8.25 \mathrm{~cm}$ diameter $\times 6 \mathrm{~cm}$ length) were also collected for the determination of the MRF (one vertical and one horizontal from each unit) and sealed in brass sleeves.

\subsection{Determination of the moisture retention function}

The MRF, or capillary pressure-saturation curve, was determined for each media following standard methods as determined by Klute (1986). The zero to atmospheric pressure range $(0-1000 \mathrm{~cm}$ water) was determined by the emplacement of the small-scale undisturbed cores into a flow cell (Soil Measurement Systems, Tuscon, AZ). For pressures exceeding atmospheric, the cores were removed from the flow cell apparatus, and placed upon large ceramic plates within the Model 1600 Pressure Extractor (SoilMoisture Co., Santa Barbara, CA).

The unsaturated hydraulic conductivity at a given pressure head $(K(h))$ of the large-scale cores was predicted using the empirical parameters obtained from the MRF. The van Genuchten (1980) equation is an empirical expression relating soil water content and tension:

$\theta=\theta_{\mathrm{r}}+\left(\theta_{\mathrm{s}}-\theta_{\mathrm{r}}\right) /\left(1+(\alpha h)^{n}\right)^{m}$

where $\theta$ is the water content, $\theta_{\mathrm{s}}$ is the water content at saturation, $\theta_{\mathrm{r}}$ is the residual water content, $h$ is the soil water tension, and $\alpha, m$, and $n$ are empirical constants that allow the model to characterize the moisture retention relationship. The MRF were simulated using the code Retention Curve (RETC) (van Genuchten et al., 1991) to determine the empirical output parameters $\alpha, n$, and $\theta_{\mathrm{r}}$ using a Mualem-based restriction $(m=1-1 / n)$ (Mualem, 1976). The output parameters of the MRF were combined with the water content and measured saturated hydraulic conductivity $\left(K_{\mathrm{s}}\right)$ of the large-scale cores to predict $K(h)$ (Table 1). The hydraulic conductivity in the large cores was measured during saturated flow by a constant-head method. $K(h)$ was not measured since these experiments were near saturation. The $K(h)$ function was used in the large core experiments to estimate the influent flow rate at a given lower boundary tension in order to establish a steady-state flux and uniform water content during a given displacement experiment.

\subsection{Experimental apparatus}

The large undisturbed cores were emplaced into PVC pipe with 3M Gray/White epoxy (3M Company, Ann Arbor, MI) and fabricated airtight acrylic endcaps were attached to the column end(s). The unsaturated experimental apparatus for the saprolite core (Jardine et al., 1993) was designed to reproduce steady-state flow under variably saturated conditions within the vadose zone in humid regions. The apparatus involves the use of a constant-head Mariotte device to supply the flow of influent under a designated tension. Tension on the lower boundary was maintained using a vacuum-regulated chamber (Soil Measurement Systems, Tucson, AZ) with an internal fraction collector (Isco Corp., Lincoln, NE). Coarse fritted glass plates (bubbling pressure $-20 \mathrm{~cm}$ ) were used on the upper and lower boundaries to maintain the flow of solution into and out of the column at a given tension, and the frits did 
Physical parameters for column displacement experiments and moisture retention functions

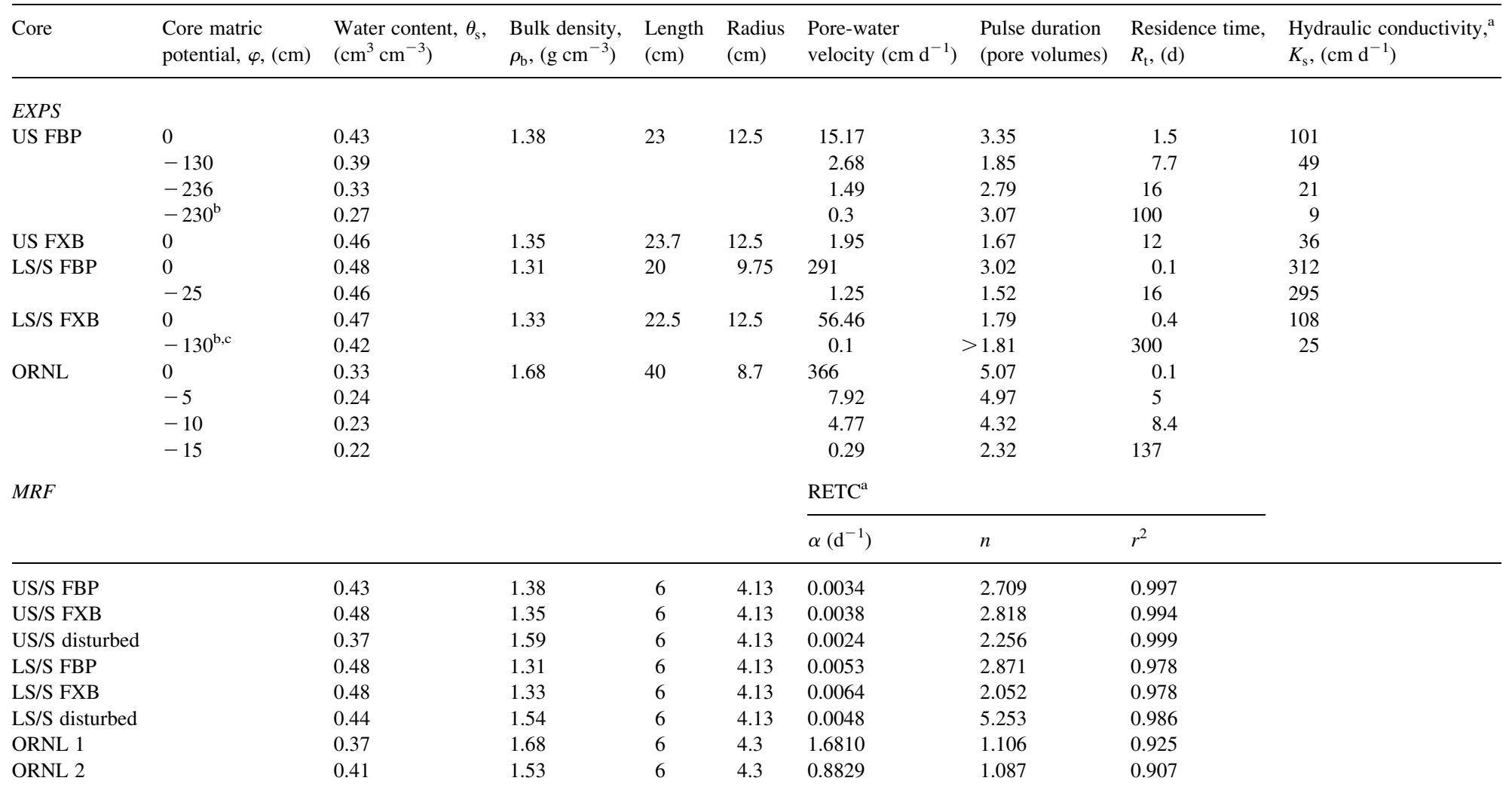

${ }^{a}$ Unsaturated conductivity predicted using RETC modeling routine parameters $\alpha$ and $n, \theta_{\mathrm{r}}=0, \theta_{\mathrm{s}}$, and $K_{\mathrm{s}}$. Saturated hydraulic conductivity $\left(K_{\mathrm{s}}\right)$ measured using constant-head method for PNNL cores only.

${ }^{\mathrm{b}}$ Experiments still in progress.

c Initial parameters provided only. 
not restrict rapid fluid flow under saturated conditions. The porous media was opened to the atmosphere during desaturation by installing several airholes along the length of the column.

Modifications to the experimental apparatus were necessary to mimic flow within the fine-grained sediments from the semi-arid region. The tension required to achieve similar water contents within the semi-arid sediments thus precluded the use of an upper boundary Mariotte device. Thus, influent delivery was accomplished by dripping solution onto an open upper soil boundary; a 12-channel peristaltic pump (Watson-Marlow Ltd, Cornwall, England) was used to maximize the distribution of solution onto the soil. A nylon membrane $(-30 \mathrm{~cm}$ bubbling pressure) was placed on the soil surface to uniformly distribute the solution. The upper boundary had an airtight seal to minimize evaporation. The flow rate was adjusted to provide a hydraulic conductivity consistent with the $K(h)$ functions described above. The tension on the lower boundary was maintained with a $-600 \mathrm{~cm}$ bubbling pressure nylon membrane (Soil Measurement Systems, Tucson, AZ) held in good contact with the media using a perforated aluminium disc that was situated within the endplate. Four tensiometers were used to monitor daily matric potential in each column. One bar standard cups (diameter $0.635 \mathrm{~cm}$, length $2.858 \mathrm{~cm}$ ) (SoilMoisture Co., Santa Barbara, CA) were emplaced $\sim 3 \mathrm{~cm}$ into the column soils.

\subsection{Miscible displacement experiments and detection of nonreactive tracers}

\subsubsection{ORNL saprolite core}

The column was saturated with $\mathrm{pH} 5.5,5 \mathrm{mM}$ $\mathrm{CaCl}_{2}$ from the lower boundary. Following saturation, a constant-head Mariotte device was used to deliver $5 \mathrm{mM} \mathrm{CaCl}_{2}$ to the upper boundary until a saturated steady flow rate was observed. The influent was changed to a nonreactive tracer solution of identical ionic strength (defined below) with infiltration continuing until the effluent concentration was equal to the influent concentration $\left(C / C_{0}=1\right)$. Once equilibrium was established, tracers were displaced with the $5 \mathrm{mM} \mathrm{CaCl}_{2}$ carrier solution until all tracer concentrations were below detection limits. Mass balance was used to confirm complete elution of tracers.
Unsaturated tracer experiments were initiated by increasing the tension on the upper and lower boundaries to the same value. The column was allowed to drain, and once a new equilibrium flow rate was established, a new tracer injection was initiated. Experiments were performed at tensions of $0,-5,-10$, and $-15 \mathrm{~cm}$.

\subsubsection{PNNL cores}

The dry weights of the columns were recorded, and corrections made for the ambient water content before saturation $(1-2 \%)$. The columns were saturated from the lower boundary with $\mathrm{pH} 8.1,5 \mathrm{mM} \mathrm{CaCl}_{2}$. Column weights were again recorded, providing an estimate of the pore volume. For the saturated flow experiments, influent delivery was accomplished using a constant head Mariotte device which maintained a ponded water depth of $\sim 1 \mathrm{~cm}$ at the upper boundary of the columns. The method of tracer delivery and washout was similar to that described above.

Following the saturated tracer experiment, the columns were attached to a vacuum-regulated chamber and allowed to drain at the desired tension until water loss from the column ceased, a period of weeks to months. The desaturated column weight was recorded, and flow of the $\mathrm{pH} 8.1,5 \mathrm{mM} \mathrm{CaCl}_{2}$ carrier solution was initiated using a multi-channel peristaltic pump. Once both constant effluent flow rate and stable tensiometer readings were achieved, the columns were weighed, and the pulse of nonreactive tracers was initiated.

In contrast, for sediment cores consisting of crossbedded material (e.g. LS/S), unsaturated experiments were conducted under transient conditions. Transient conditions were indicated by a directional change in the water content, and such conditions were due to physical attributes of the media. The unsaturated experiment was conducted by infiltrating 0.51 of $\mathrm{CaCl}_{2}$ for $\sim 2$ weeks, followed by a switch to the multiple nonreactive tracer solution.

Three nonreactive tracers, bromide, pentafluorobenzoic acid (PFBA), and piperazine-1, 4-bis(2ethanesulfonic acid) (PIPES), were used to identify diffusional processes during transport. Molecular size is the primary control upon the rate of diffusion, i.e. larger molecules diffuse more slowly and vice versa. Fig. 2 shows the chemical structures of each molecule, 
<smiles>O=C(O)c1c(F)c(F)c(F)c(F)c1F</smiles>

(b)

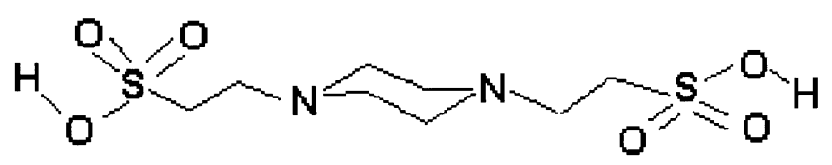

Fig. 2. Chemical structures of nonreactive tracers (a) PFBA (pentafluorobenzoic acid) and (b) PIPES (piperazine-1,4-bis(2-ethanesulfonic acid)).

and Table 2 provides each free-water diffusion coefficient and $\mathrm{p} K_{\mathrm{a}}$. The free-water diffusion coefficients for PIPES and PFBA have been calculated according to the Hayduk and Laudie (1974) method (Tucker and Nelken, 1982). This equation applies to large, spherical molecules diffusing in a continuous solution (Tucker and Nelken, 1982). The Hayduk and Laudie method varied from published estimates for PFBA by $\sim 5 \%$ (e.g. Bowman, 1984); this method was chosen for internal consistency between PIPES and PFBA (Table 2). No published estimates of the diffusion coefficient are available for PIPES, and it should be noted that the linear shape of the molecule could result in greater variation in its rate of diffusion (Fig. 2).

PFBA has been investigated and widely used as a nonreactive tracer (Bowman, 1984; Bowman and Gibbens, 1992; Hu and Brusseau, 1994, 1995; Langner et al., 1999; Gamerdinger and Kaplan, 2000; McCarthy et al., 2000). PIPES is a biological buffer developed for maximum solubility, minimal interaction with mineral cations, and minimal biological reactions in the $\mathrm{pH}$ range of 6-8 (Good et al., 1966). It has been utilized as a nonreactive tracer in Jardine and Taylor (1995) and Moline et al. (2001). The influent solutions used in the displacement experiments described above consisted of the following components: $0.5 \mathrm{mM}$ $\mathrm{Br}^{-}$as $\mathrm{CaBr}_{2}, 0.5 \mathrm{mM}$ PFBA, and $1.0 \mathrm{mM}$ PIPES, $4.4 \mathrm{mM} \mathrm{CaCl}_{2}$, and $2.4 \mathrm{mM} \mathrm{KOH}$, resulting in an equivalent ionic strength for both influent and carrier solutions $(I=0.015 \mathrm{M})$. KOH was used to adjust the $\mathrm{pH}$ of the influent solution to the $\mathrm{pH}$ of the soil, which was generally around $7.8-8.0$ for the PNNL sands/silts, and 5.5 for the ORNL saprolite. Experiments involving the saprolite did not contain PIPES since the tracer was observed to react with the soil at the $\mathrm{pH}$ of 5.5 (see $\mathrm{p} K_{\mathrm{a}}$ Table 2).

Quantification of the $\mathrm{Br}^{-}$, PFBA, and PIPES was accomplished via UV detection $(190 \mathrm{~nm})$ in a lowpressure liquid chromatography system using the IonPac AS-4A column (Dionex Corp. Model DX-300 Gradient Pump, Sunnyvale, CA). Eluent was $1.6 \mathrm{mM}$ $\mathrm{HCO}_{3}^{-}$and $1.6 \mathrm{mM} \mathrm{CO}_{3}^{2-}$ for the elution of $\mathrm{Br}^{-}$and PFBA (3.0 and $3.2 \mathrm{~min}$ ); eluent concentration was increased at $1.8 \mathrm{~min}$ to $4.8 \mathrm{mM} \mathrm{HCO}_{3}^{-}$and $4.8 \mathrm{mM}$ $\mathrm{CO}_{3}^{2-}$ to speed the elution of PIPES at $6.8 \mathrm{~min}$. Detection limits were approximately $0.005 \mathrm{mM}$ for $\mathrm{Br}^{-}$and PFBA, and $0.02 \mathrm{mM}$ for PIPES, as determined by standard curves.

Table 2

Specifications of nonreactive tracers

\begin{tabular}{lll}
\hline Tracer & $\begin{array}{l}\text { Diffusion coefficient, } \\
\left(D_{\mathrm{e}}\right),\left(\mathrm{m}^{2} \mathrm{~s}^{-1}\right)\end{array}$ & $\mathrm{p} K_{\mathrm{a}}$ \\
\hline $\mathrm{Br}^{-}$ & $18.7 \times 10^{-10 \mathrm{a}}$ & - \\
PFBA & $7.8 \times 10^{-10 \mathrm{~b}}$ & $2.7^{\mathrm{c}}$ \\
PIPES & $5.2 \times 10^{-10 \mathrm{~b}}$ & $<3,6.8^{\mathrm{d}}$ \\
\hline
\end{tabular}

a Bowman (1984).

b Calculated by the Hayduk and Laudie (1974) method (Tucker and Nelken, 1982).

c McCarthy et al. (2000).

${ }^{\mathrm{d}}$ Good et al. (1966). 


\section{Results and discussion}

\subsection{Moisture retention functions}

The PNNL U. Ringold sediments remained saturated until $\sim 100 \mathrm{~cm}$ tension was exceeded (Fig. 3). This was true for both sedimentary units (US and LS/S), for horizontal (FBP) and vertical (FXB) cores, and for undisturbed versus disturbed repacked cores. Moisture retention characteristics were a function of particle size, where the media was fine-grained, well-sorted silty sand. Other sediments analyzed from the Hanford reservation lost water much earlier in the function (Bjornstad, 1990; Connelly et al., 1992), which suggests that our material contains appreciably more silt and fines than materials used in previous studies.

The undisturbed US FBP and FXB were nearly indistinguishable from one another (Fig. 3a), while minor differences between the LS/S FBP and FXB were observed (Fig. 3b). This suggested that the water holding capacity of the soils as a function of pressure was independent of bedding orientation, though it should be noted that the wetting curve was not determined. The LS/S cores, which contained more sand and less silt and clay, lost their moisture somewhat faster than the US cores. Disturbed samples of the LS/S and US units resulted in slightly different MRF from the undisturbed samples. Both were unintentionally packed to a bulk density slightly greater than the undisturbed cores (Table 1), but the LS/S lost moisture faster, while the US lost moisture more slowly, than their undisturbed counterparts. Model fits with the RETC routine (van Genuchten et al., 1991) were generally in good agreement with the observed data (Fig. 3).

MRFs for the ORNL saprolite (Fig. 3b) differed from that of the unconsolidated sands of the Ringold, due to the greater influence of media structure vs. grain size. Significant breaks in slope suggested multi-region porosity; e.g. macro-, meso-, and microporosity, which has been previously observed in this highly weathered, fractured material (Wilson et al., 1992). Macropores are defined as fractures or pores $>1000 \mu \mathrm{m}$, mesopores are defined as $10-1000 \mu \mathrm{m}$, and micropores are defined as $<10 \mu \mathrm{m}$ (Luxmoore, 1981; Wilson and Luxmoore, 1988). The loss of soil water by $-10 \mathrm{~cm}$ tension was primarily due to the dewatering of primary fractures and/or macropores, which should be highly conductive under saturated conditions. The shale saprolite used in this study lost $20-25 \%$ of its water between 0 and $-10 \mathrm{~cm}$, compared to $8-11 \%$ in samples used by Wilson et al. (1992). The material of the current study differ from those of Wilson et al. (1992) in that they are dominated by hard shale saprolite with less illuviated clay and clay lenses. This behavior was not fully reproduced by the RETC modeling routine (Fig. 3b). Complete water loss was not observed throughout the range of tensions applied, probably because many matrix blocks became isolated in the highly fractured material.

The water retention properties of these soils and sediments were used to predict unsaturated hydraulic conductivity $(K(h))$ functions (Table 1$)$ in order to estimate the influent flow rate at different water contents in the large core displacement experiments described below.

\subsection{Miscible displacement experiments, ORNL saprolite}

The ORNL saprolite exhibited classic multi-region behavior, such that tracer transport was governed by both preferential flow and matrix diffusion within this highly fractured, structured media (Fig. 1a). Flow through large fractures, e.g. macropores, governed tracer flux during saturated flow, as indicated by the rapid breakthrough of tracer (Fig. 4b). However, considerable tailing was observed, which suggested the influence of matrix diffusion (Fig. 4a). The observed separation of the two tracers confirmed that diffusional processes were operative (Fig. 4b). These tracers have different free-water diffusion coefficients, with the coefficient of $\mathrm{Br}^{-}$being $\sim 2.5$ times larger than that of PFBA (Table 2). During preferential flow, solute diffuses into the fine-grained matrix due to concentration gradients such that smaller ions with larger diffusion coefficients will be more rapidly transferred into the matrix (Jardine et al., 1998). Thus, the effluent concentration of $\mathrm{Br}^{-}$was consistently lower than that of PFBA during the breakthrough portion of the experiments (Fig. 4b). The opposite was true for the washout portion, in 

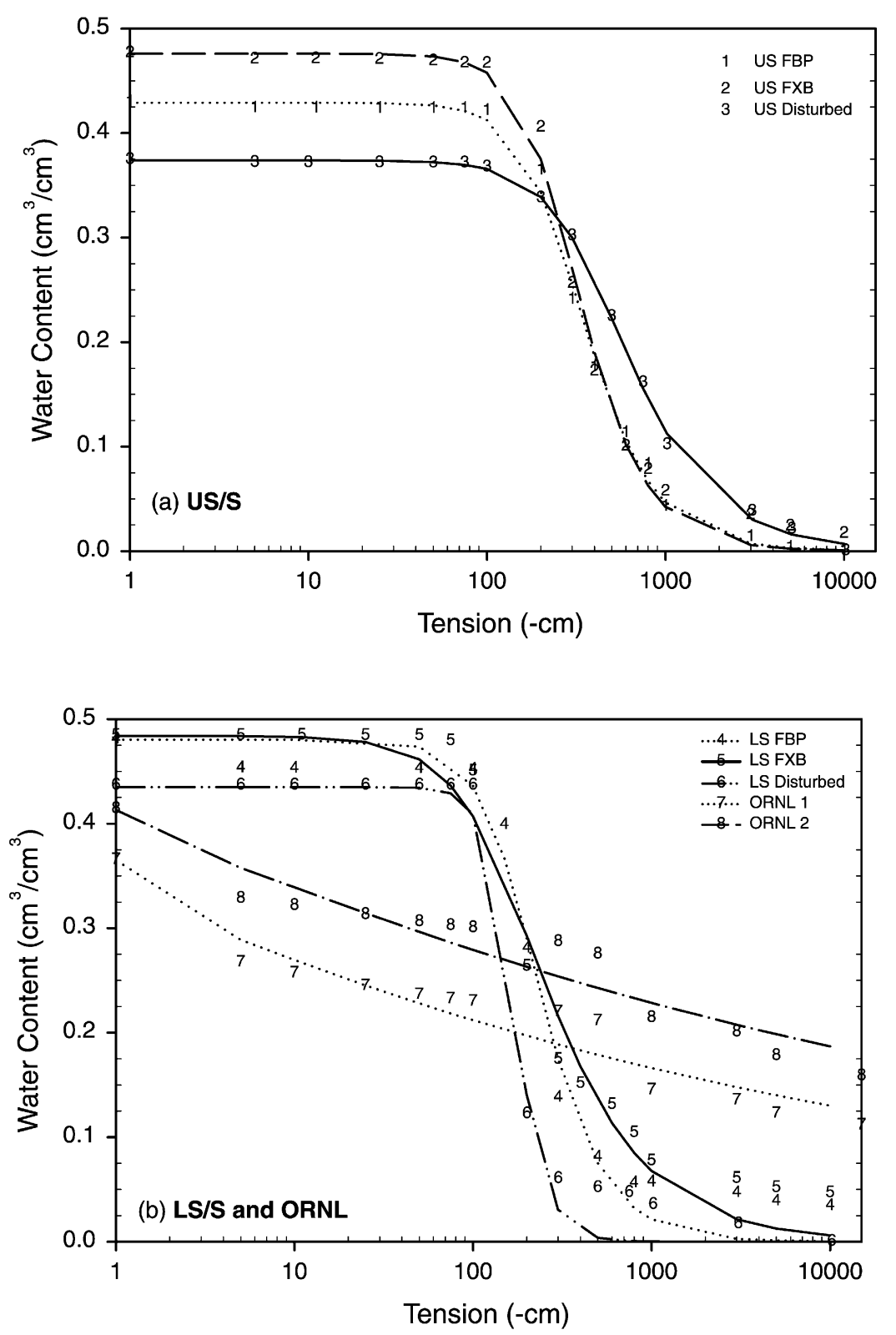

Fig. 3. Moisture Retention Functions (MRF) of PNNL and ORNL small-scale cores. (a) Observed US data points: 1, flow bedding parallel core; 2, flow bedding perpendicular core; 3, disturbed core. Lines represent simulated MRF by the RETC code. (b) Observed LS/S and ORNL data points: 4, LS/S flow bedding parallel core; 5 , LS/S flow bedding perpendicular core; 6, LS/S disturbed core; 7, ORNL 1; 8, ORNL 2. Lines represent simulated MRF by the RETC code.

which $\mathrm{Br}^{-}$diffused more quickly out of the soil matrix than PFBA.

Asymmetric BTC indicative of preferential flow were observed in the -5 and $-10 \mathrm{~cm}$ experiments also (Fig. 4a). Observed flux rates, however, were two orders of magnitude lower than saturated flux rates, which suggests that macropores were no longer active or contributing to flow. Thin film flow may occur on fracture and/or bedding plane surfaces, however, (Tokunaga and Wan, 1997; Tokunaga et al., 2000). 

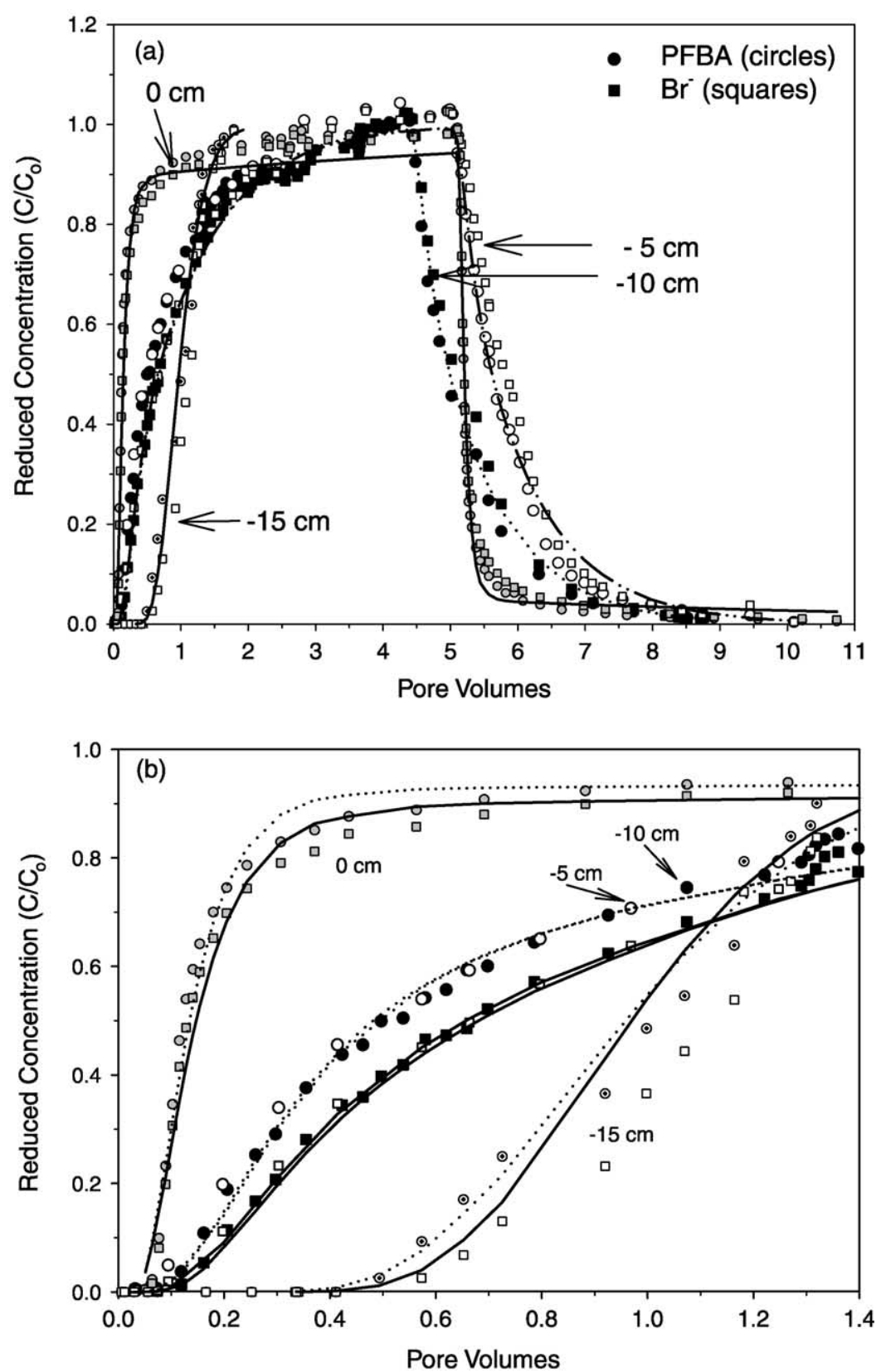

Fig. 4. Observed (points) and model fitted (lines) tracer effluent concentrations involving the displacement of $\mathrm{Br}^{-}$(squares) and PFBA (circles) at tensions of $0,-5,-10$, and $-15 \mathrm{~cm}$ through the ORNL undisturbed core. (a) Simulations of $\mathrm{Br}^{-}$(only) shown to improve clarity of figure. (b) Simulations of $\mathrm{Br}^{-}$are solid lines, while PFBA simulations are dotted lines. Model parameters are provided in Tables 1 and 3.

Greater separation between $\mathrm{Br}^{-}$and PFBA was observed compared to saturated flow. This may be due to a greater residence time associated with a lower flow velocity (Akratanakul et al., 1983; Smettem,
1984; Seyfried and Rao, 1987; Jardine et al., 1988, 2001). Very little difference was observed between the -5 and $-10 \mathrm{~cm}$ injections, which indicated that the same set of pores was active at these two tensions. 
Table 3

Results of application of CDE and MIM to miscible displacement experiments

\begin{tabular}{|c|c|c|c|c|c|c|c|c|c|c|c|c|}
\hline Core & $\begin{array}{l}\text { Pressure head } \\
(\mathrm{cm})\end{array}$ & Model & $\begin{array}{l}\text { Peclet number }\left(P_{\mathrm{e}}\right) \\
\mathrm{Br}^{-}\end{array}$ & $\begin{array}{l}R^{2} \\
\mathrm{Br}^{-}\end{array}$ & $\begin{array}{l}\text { Peclet number }\left(P_{\mathrm{e}}\right) \\
\text { PFBA }\end{array}$ & $\begin{array}{l}R^{2} \\
\text { PFBA }\end{array}$ & $\begin{array}{l}\text { Peclet number }\left(P_{\mathrm{e}}\right) \\
\text { PIPES }\end{array}$ & $\begin{array}{l}R^{2} \\
\text { PIPES }\end{array}$ & $\begin{array}{l}F \\
\mathrm{Br}^{-}\end{array}$ & $\begin{array}{l}F \\
\text { PFBA }\end{array}$ & $\begin{array}{l}\text { Transfer rate, } \\
\alpha,\left(\mathrm{d}^{-1}\right) \\
\mathrm{Br}^{-}\end{array}$ & $\begin{array}{l}\text { Transfer rate } \\
\alpha,\left(\mathrm{d}^{-1}\right) \\
\text { PFBA }\end{array}$ \\
\hline US FBP $^{\mathrm{a}}$ & 0 & $\mathrm{CDE}$ & $5.06 \pm 0.73^{\mathrm{b}}$ & 0.990 & $5.70 \pm 0.91$ & 0.990 & $4.86 \pm 0.69$ & 0.990 & & & & \\
\hline & -130 & $\mathrm{CDE}$ & $7.50 \pm 1.35$ & 0.959 & $7.76 \pm 2.33$ & 0.957 & $6.95 \pm 1.64$ & 0.966 & & & & \\
\hline & -236 & $\mathrm{CDE}$ & $6.98 \pm 0.81$ & 0.993 & $7.19 \pm 1.28$ & 0.991 & $7.77 \pm 1.27$ & 0.982 & & & & \\
\hline US FXB & 0 & CDE & $20.05 \pm 4.53$ & 0.966 & $18.69 \pm 5.68$ & 0.976 & $20.70 \pm 8.92$ & 0.968 & & & & \\
\hline $\mathrm{LS} / \mathrm{S} \mathrm{FXB}^{\mathrm{a}}$ & 0 & $\mathrm{CDE}$ & $66.25 \pm 13.68$ & 0.968 & $67.18 \pm 22.39$ & 0.967 & $69.38 \pm 23.98$ & 0.967 & & & & \\
\hline \multicolumn{13}{|l|}{ ORNL } \\
\hline & 0 & MIM & $5.34 \pm 0.91$ & 0.987 & $6.30 \pm 1.03$ & 0.989 & & & 0.16 & 0.14 & 0.339 & 0.234 \\
\hline & -5 & MIM & 4.23 & & 3.96 & & & & 0.48 & 0.45 & 0.110 & 0.020 \\
\hline & -10 & MIM & $4.73 \pm 1.27$ & 0.995 & 3.81 & & & & 0.48 & 0.45 & 0.030 & 0.014 \\
\hline & -15 & CDE & $23.36 \pm 8.88$ & 0.940 & $19.47 \pm 4.82$ & 0.981 & & & & & & \\
\hline
\end{tabular}

Note that experiments in progress were not included

${ }^{b}$ Model fit 95\% confidence interval shown. 
The significant difference between tracer BTCs at 0 and $-5 \mathrm{~cm}$ suggests that the transition between macropore and mesopore flow may occur between those two tensions.

Results from the $-15 \mathrm{~cm}$ experiment indicated that nearly all fracture flow was eliminated as evidenced by the highly symmetric BTC (Fig. 4a) and the time required for completion of the influent injection $(\sim 1 \mathrm{yr})$. Further, initial breakthrough of tracers only occurred after 2 months and $>1000 \mathrm{~cm}^{3}$ of eluted solution. This suggested that the movement of water and solutes through the media was restricted
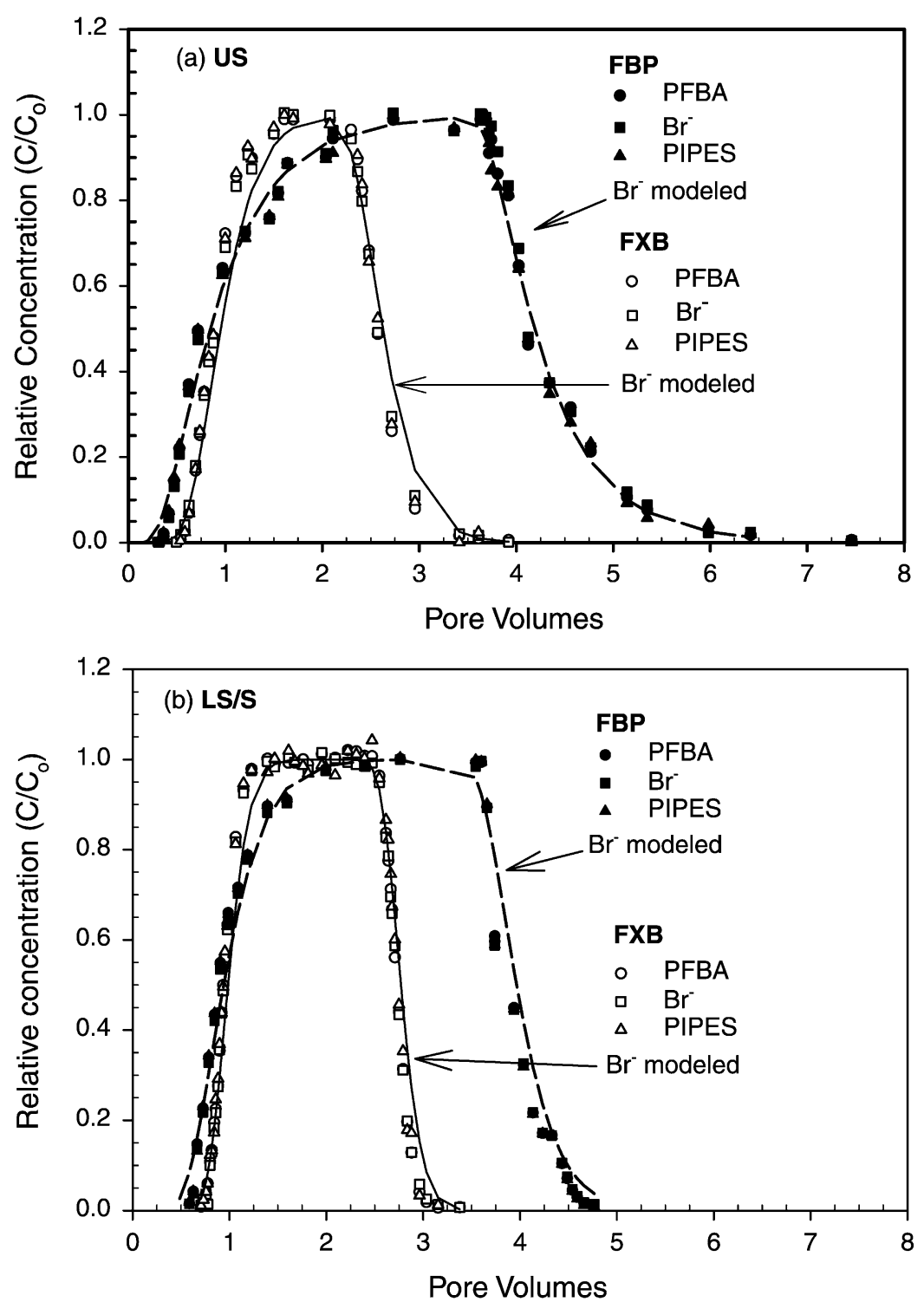

Fig. 5. Observed (points) and model fitted (lines) tracer effluent concentrations involving the displacement of Br ${ }^{-}$, PFBA, and PIPES through saturated PNNL cores. Modeled $\mathrm{Br}^{-}$concentrations are shown. Modeled PFBA and PIPES were omitted to improve clarity of figure, since no significant differences in modeled BTCs were observed. (a) Observed relative concentrations in the US unit for flow bedding parallel (FBP) cores and flow bedding perpendicular (FXB) cores. (b) Observed relative concentrations in the LS/S unit for FBP and FXB cores. Model parameters are provided in Tables 1 and 3 . 
to a smaller, more homogenous pore regime. It is interesting to note that nonequilibrium processes persisted at the $-15 \mathrm{~cm}$ tension even though fracture flow was essentially eliminated. The separation of the two tracers suggested multi-region flow remained effective under conditions of very slow flow $\left(0.29 \mathrm{~cm} \mathrm{~d}^{-1}\right)$ (Table 1).

Transport parameters for the $0,-5$, and $-10 \mathrm{~cm}$ experiments were determined using the mobileimmobile (MIM) model in CXTFIT (Parker and van Genuchten, 1984). The nonequilibrium behavior of tracer breakthrough was captured with MIM model fits, which were consistently better than model fits with the classical CD equation. Predicted values of $F$ (fraction of mobile water) increased with decreasing saturation, which is consistent with the exclusion of fracture flow during unsaturated solute displacement (Table 3). For saturated conditions, the proportion of mobile water was determined to be $14 \%$ for PFBA and $16 \%$ for $\mathrm{Br}^{-}$, which indicated that a relatively small proportion of highly conductive fractures was present in this media. These results were consistent with water retention functions that estimated $20-25 \%$ of the saturated pores were occupied by mobile water. As the media desaturates, the type of mobile water changes since fractures contribute less to solute transport. Under these conditions, the transport of water and solute is restricted to a more homogenous set of smaller pore regimes but the mobile water fraction increases due to decreasing pore class heterogeneity. Although multi-region flow was apparent during the $-15 \mathrm{~cm}$ displacement experiment, the results were adequately described by the classical $\mathrm{CD}$ equation suggesting $100 \%$ mobile water. These results suggest that the model is not sensitive enough to detect the extent of nonequilibrium, and a more mechanistic code would be necessary to rigorously simulate this process. Model-fitted Peclet numbers $\left(P_{\mathrm{e}}\right)$ and mass transfer coefficients were consistent with the findings of others, suggesting an increase in $P_{\mathrm{e}}$ and $\alpha$ with decreasing saturation of the media (Table 3 ).

\subsection{Miscible displacement experiments, PNNL U. Ringold Fm}

In contrast to the multi-region behavior exhibited by the ORNL saprolite, physical nonequilibrium (PNE) in the PNNL laminated silts and sands was influenced by the orientation of bedding and antecedent water content. The relative conductivity of lateral versus vertical flow may be inferred by comparison of saturated flow through the FBP and FXB cores (Fig. 5). The FBP cores generated more asymmetric BTCs in contrast to the more symmetrical BTCs of the FXB cores, probably due to the presence of bedding-parallel flow in the former core type. This hypothesis is supported by the hydraulic conductivities of the FBP cores, which were three times greater than those of FXB cores (Table 1), and $P_{\mathrm{e}}$ of FBP cores, which were significantly less than those of FXB cores (Table 3). The high degree of symmetry of the FXB BTCs further suggested that vertical preferential flow features (fractures, joints, or other lithologic contacts) were absent. Therefore, the conductivity of the FXB cores was probably limited by the least conductive beds.

The influence of nonequilibrium processes was investigated using multiple nonreactive tracers. No separation of tracers occurred under saturated conditions in either the FBP or FXB cores (Fig. 5). This suggested that the mechanism of matrix diffusion was minimal in these sediments under saturated conditions, and that the formation of immobile water was negligible or very small. Therefore the observed BTC asymmetry and low $P_{\mathrm{e}}$ obtained for the FBP cores must result from the dominance of advective vs. diffusive transport processes (Becker and Shapiro, 2000). Because tracer separation was not observed, the CDE was appropriate to model the data, and only fits to the $\mathrm{Br}^{-}$BTC were shown (Figs. 5 and 6). The MIM was tested since there may have been a small fraction of immobile water and because previous studies have used this model for saturated flow in repacked sediments (Bond and Wierenga, 1990; Padilla et al., 1999; Gamerdinger and Kaplan, 2000). Our results suggested that the CDE could adequately describe the observed data and that the MIM was not necessary (Table 3).

Decreasing the water content in the US FBP core had only a slight effect upon tracer transport. Overall, similar BTCs and $P_{\mathrm{e}}$ were obtained for saturated and unsaturated $\left(100\left(\theta / \theta_{\mathrm{s}}\right)=96,78\right.$, and $\left.66 \%\right)$ experiments (Fig. 6a, Table 3). The absence of tracer separation (Fig. 7a) suggested that nonequilibrium processes (preferential flow, matrix diffusion, formation of immobile water) were minimal in the US 

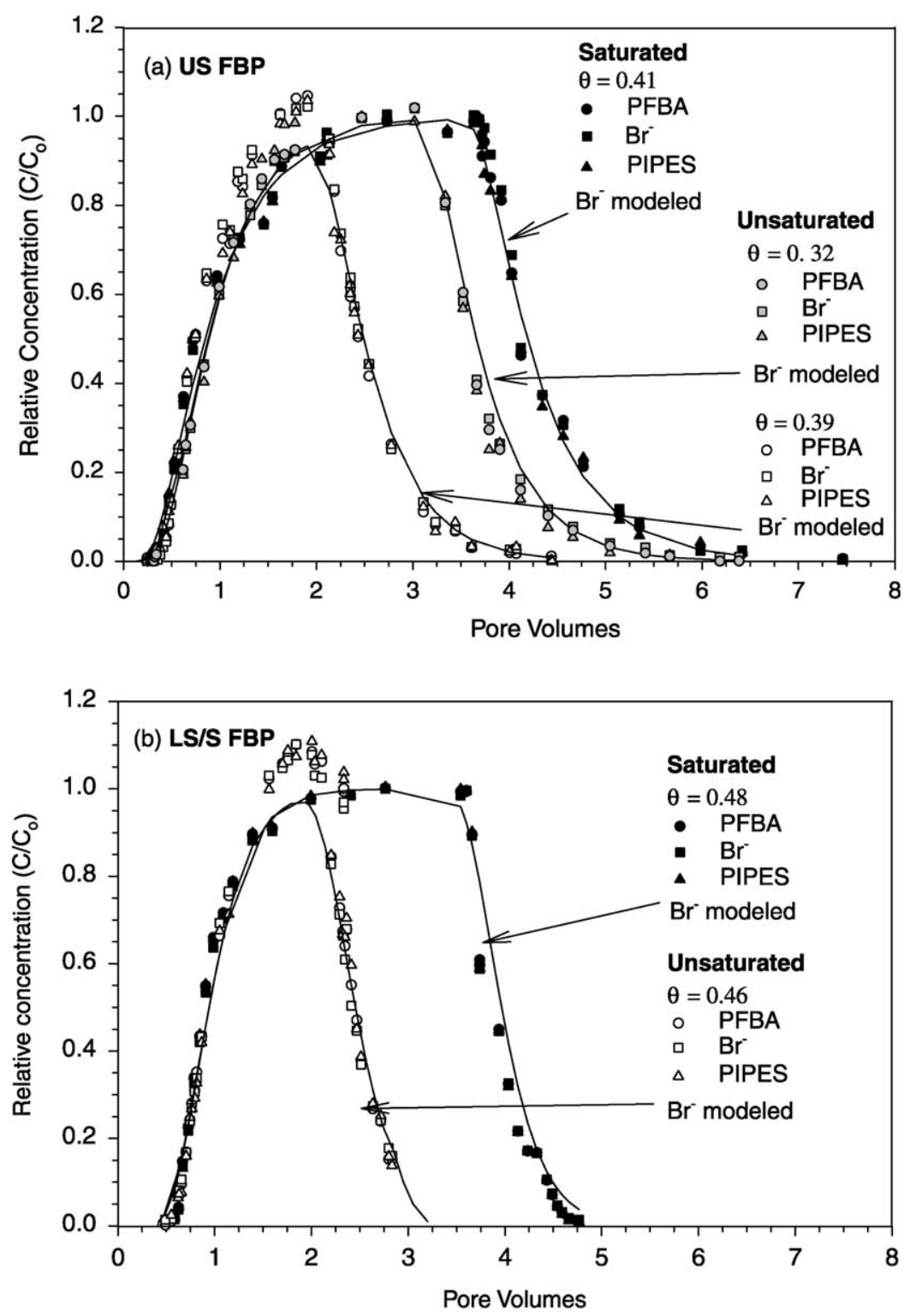

Fig. 6. Observed (points) and model fitted (lines) tracer effluent concentrations involving the displacement of $\mathrm{Br}^{-}$, PFBA, and PIPES through variably saturated PNNL FBP cores. Modeled $\mathrm{Br}^{-}$concentrations are shown. PFBA and PIPES were omitted to improve clarity of figure, since no significant differences in modeled BTCs were observed. (a) Observed relative concentrations in the US FBP core under tensions of $0,-130$, and $-246 \mathrm{~cm}$. (b) Observed relative concentrations in the LS/S FBP core under tensions of 0 and $-25 \mathrm{~cm}$. Model parameters are provided in Tables 1 and 3 .

FBP core. Consequently, the CDE adequately modeled the transport experiments, and similar $P_{\mathrm{e}}$ were obtained for saturated and unsaturated conditions (Table 3). For all unsaturated experiments in the US FBP core, a uniform water content and matric potential were observed, which suggested the propensity of steady-state flow during unsaturated conditions (Fig. 8). Continuous, horizontal beds parallel to the length of the core probably conduct most of the flow (Fig. 1b). Asymmetric BTCs observed under saturated 

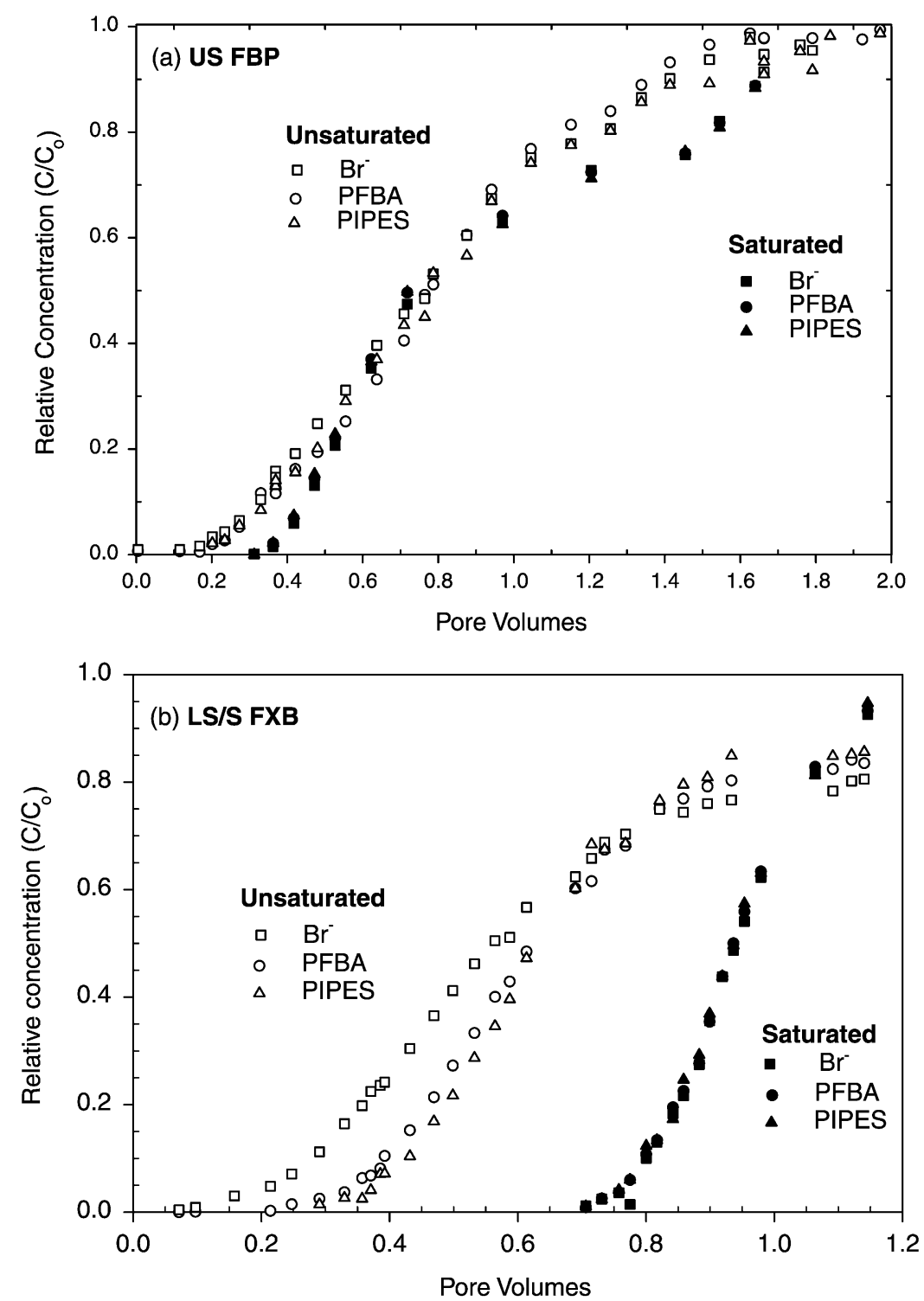

Fig. 7. Observed tracer effluent concentrations involving the displacement of $\mathrm{Br}^{-}, \mathrm{PFBA}$, and PIPES through variably saturated PNNL cores. Experiments are still in progress and as much data as is available is shown here. (a) Observed relative concentrations for the $0-2$ pore volume range in the US FBP core under tensions of 0 and $-230 \mathrm{~cm}$. (b) Observed relative concentrations for the $0-1.2$ pore volume range in the LS/S FXB core under tensions of 0 and $-130 \mathrm{~cm}$.

conditions are likely a result of flow along and parallel to bedding. As water content decreases, these bedding planes and coarser beds desaturate, which most likely prevents the exchange of water and solutes between adjacent beds. Under unsaturated conditions, successively lower water contents resulted in earlier initial breakthrough of tracers (Fig. 7a) and greater tailing as suggested by longer influent pulse durations (Table 1). This suggests that the influence of pore-scale velocity heterogeneities among beds of varying grain size become more apparent with decreasing water content (Padilla et al., 1999). 

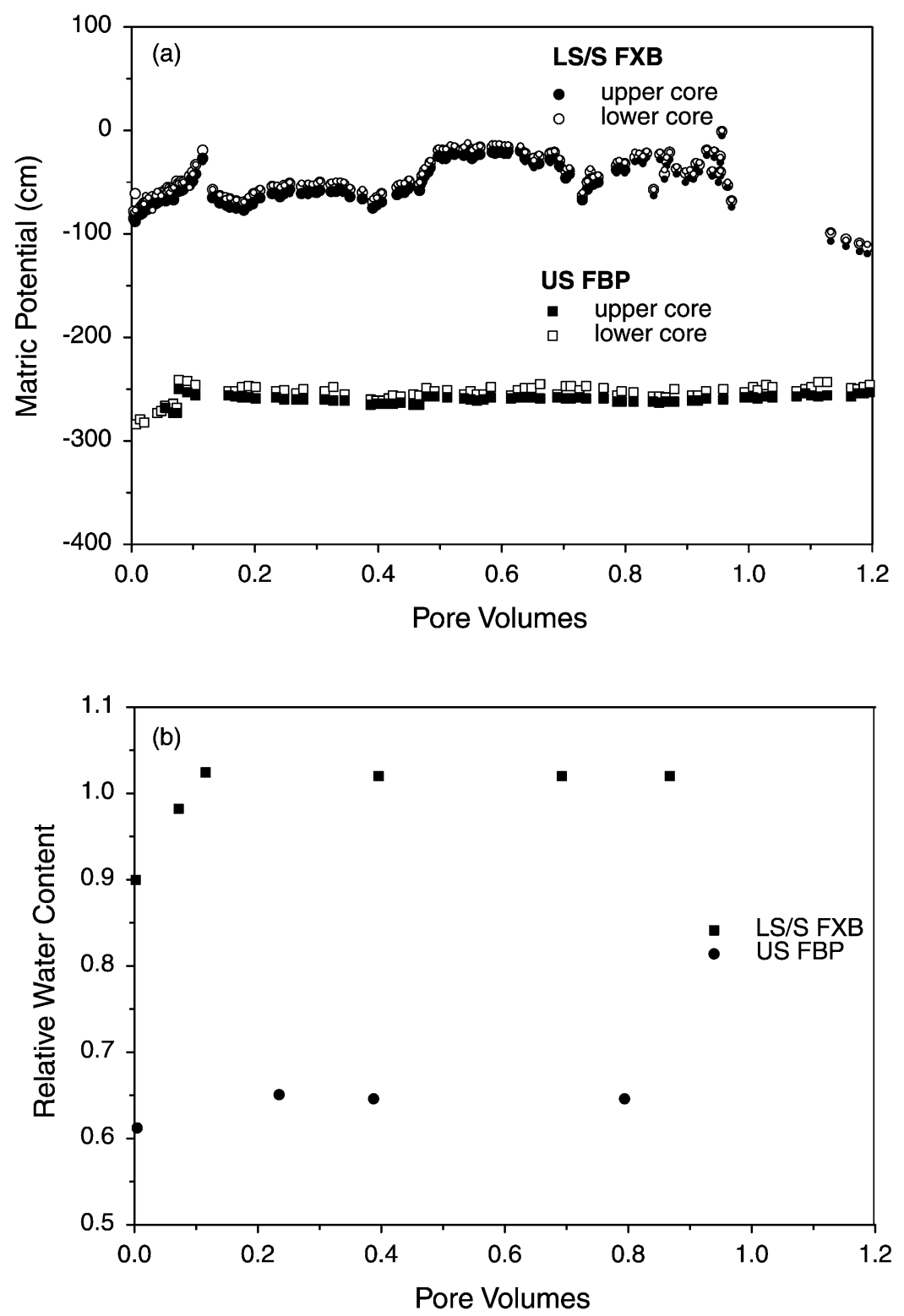

Fig. 8. Hydraulic parameters for the unsaturated experiments of Fig. 7, 0-1.2 pore volume range. Applied tension at lower boundary was $-195 \mathrm{~cm}$ for LS/S FXB, and $-360 \mathrm{~cm}$ for US FBP. (a) Observed core matric potential as inferred by averaged tensiometer readings and, (b) relative water content as inferred by gravimetric analysis.

The LS/S FBP core exhibited similar behavior as the US FBP core in that an asymmetric BTC was observed under saturated conditions, while unsaturated flow (96\% water content) resulted in increased symmetry (Fig. 6b). Similar $P_{\mathrm{e}}$ were obtained for both experiments (Table 3) and no evidence of PNE was observed.

In contrast, the LS/S FXB core where flow crosscuts sedimentary beds (e.g. Fig. 1c) exhibited nonequilibrium behavior under unsaturated conditions. 
This interpretation is supported by three observations; (1) tracers exhibited early breakthrough and extended tailing relative to saturated conditions, which indicates that a portion of the media has been bypassed (i.e. preferential flow) (Fig. 7b); (2) separation of the tracers was observed which indicates an interaction between preferential flowpaths and a portion of relatively immobile water (Fig. 7b); and (3) an increase in water content from 90 to near $100 \%$ was observed during the course of the experiment, with corresponding decrease in core matric potential (Fig. 8). These results are supported by additional unsaturated experiments through the US FXB core (96\% initial water content) and the LS/S FBP core (58\% initial water content), where the latter core exhibits large discontinuous bedding features as shown in Fig. 1d (Mayes et al., 2003). The increase in water content to near saturation was consistent for each of these materials under unsaturated conditions, regardless of the initial water content, influent flux rate, or lower boundary tension.

All of these observations are consistent with the development of an unstable wetting front characterized by coupled preferential finger flow and relatively immobile perched water. The occurrence is limited to unsaturated conditions in cores with discontinuous bedding (e.g. FXB cores and LS/S sedimentary unit at lower water contents). This suggests that steady-state unsaturated flow became disrupted when crossing lithologic discontinuities (Fig. 1c and d). Note that this contrasts with transport through the US FBP core, where continuous parallel beds (Fig. 1b) conducted water under unsaturated, steady-state conditions. The development of an unstable wetting front has been attributed to hysteresis in the MRF (Glass et al., 1988, 1989; Hillel and Baker, 1988; Ritsema et al., 1998; Sililo and Tellam, 2000). The simplest analogy provided by previous studies utilizes a fine layer overlying a coarse layer (Glass et al., 1988, 1989; Sililo and Tellam, 2000). Stable flow advances through the fine-grained layer, but movement into an underlying drier, coarse-grained layer will be unstable, resulting in the development of wet, fastflowing fingers separated by drier, less conductive regions. This suggests that some degree of perching in the overlying fine-grained layers would be required to initiate flow into the drier underlying coarse layers, which act as capillary barriers (Hillel and Baker,
1988). This interpretation is consistent with the observed increase in local-scale water content to near saturation during the experiment (Fig. 8). Drainage of the core probably caused different antecedent water contents to exist between adjacent beds of variant grain sizes. Beds within the finegrained U. Ringold sediments are on the $\mathrm{mm}$ - to cmscale, so tens to hundreds of beds may be present in each $25 \mathrm{~cm}$ core (Fig. 1b-d). This suggests that differences in grain size and water content between adjacent sedimentary beds are the primary control for the development of preferential flow and immobile water in unconsolidated media.

The consistency of these results with experiments performed on initially dry porous media (Glass et al., 1988; 1989; DiCarlo et al., 1999; Sililo and Tellam, 2000) is surprising due to the high initial water content $(90 \%)$ of the LS/S FXB experiment (Figs. 7b and $8 \mathrm{~b}$ ). Previous studies have shown the propensity for preferential finger flow may be eliminated in the presence of small amounts of antecent water (Diment and Watson, 1985; Porro and Wierenga, 1993) or are dampened at higher water contents (Bauters et al., 2000). Steady-state, miscible displacement experiments performed under unsaturated conditions at higher water contents ( $14 \%$ to near saturation), however, have resulted in preferential flow and immobile water, which is consistent with our results (Padilla et al., 1999; Gamerdinger and Kaplan, 2000). Our results extend the observations of unstable finger flow to more saturated conditions than previous studies might suggest. The use of undisturbed, complex layered materials in the current study certainly contributes to the development of the numerous local-scale unstable fronts, which accentuates the formation of perched water, unstable finger flow, and the formation of immobile water regimes.

Tracer separation during solute breakthrough in the unsaturated FXB core suggests that diffusional processes are active, which is generally attributed to the presence of 'immobile' water. During the breakthrough portion of the curve, the order of tracer breakthrough in the PNNL cores is the opposite of that observed in the ORNL cores (compare Figs. 7b and $4 \mathrm{~b})$. The similarity of the breakthrough portion of the PNNL cores with the washout portion of the ORNL cores suggests similar governing processes, i.e. immobile regions of water provide a source from 
which solutes diffuse into preferential flowpaths. Previous studies have identified three stages regarding infiltration into layered sands and silts: rapid formation of fingers, slow lateral wetting of surrounding media from finger cores (redistribution), and steadystate persistence of conductive fingers surrounded by relatively nonconducting media (Glass et al., 1988, 1989; Hillel and Baker, 1988; DiCarlo et al., 1999; Bauters et al., 2000; Sililo and Tellam, 2000). In the current study, the initial formation of fingers probably occurred during the initial two weeks of $\mathrm{CaCl}_{2}$ infiltration that preceded the tracer injection. The bulk water content continued to increase during the tracer injection (Fig. 8), which suggests that the wetting front was in the redistribution phase in which water moves laterally from finger cores into surrounding media. The end of the redistribution phase, denoted by constant tension and water content, was obtained concurrently with initial tracer breakthrough (compare Figs. $7 \mathrm{~b}$ and 8). This suggests that the immobile water developed during the redistribution phase may have provided a source for tracers, which subsequently diffused into faster-flowing fingers. This scenario would likely yield a solute breakthrough profile in which the most rapidly diffusing tracer $\left(\mathrm{Br}^{-}\right)$would arrive in the effluent first and at higher concentrations (Fig. 7b) relative to tracers with smaller diffusion coefficients (e.g. PFBA followed by PIPES).

The dichotomy concerning the order of tracer elution during the breakthrough portion of the curve between structured soils from humid regimes and semi-arid region sediments has not previously been observed. We believe this is due to our experimental technique, which has not previously been utilized on undisturbed sediments from semi-arid regions. Both co-elution (Figs. 5-7a) and separation (Fig. 7b) of tracers were observed, which suggests that hydrologic, rather than chemical processes such as anion exclusion (James and Rubin, 1986; Porro and Wierenga, 1993), can provide an explanation for the observed tracer separation.

\section{Conclusions}

Multiple nonreactive tracer experiments through variably saturated undisturbed cores from humid and semi-arid climatic regimes confirmed that similar bulk hydrologic processes control solute fate and transport in these very different soil types. For structured humid regime soils, immobile water was present regardless of water content, while the occurrence of preferential flow decreased with decreasing water content. For laminated sediments from semi-arid regions, saturated flow was marked by an advective-dominated flow regime, whereas the occurrence of preferential finger flow and perched immobile water increased with decreasing water content.

In the fractured ORNL saprolite, a multiple nonreactive tracer injection strategy confirmed the importance of matrix diffusion to the overall PNE process controlling solute migration. The fractured saprolites at ORNL are conducive to extreme preferential flow that results in PNE between fractures and the surrounding soil matrix. Greater separation in tracer breakthrough was observed with decreasing water content, due to increased residence times and a greater opportunity for solute mass to diffuse into immobile water regimes. The prevalence of nonequilibrium conditions under saturated and unsaturated conditions suggests that the existence of the majority of contaminant residing in the soil matrix greatly retards bulk contaminant mass migration rates.

In the laminated sediments from PNNL, nonequilibrium transport was observed exclusively during unsaturated flow across discontinuous sedimentary beds in the undisturbed cores. Such nonequilibrium transport resulted in the development of an unstable wetting front, local-scale regions of perched immobile water, and preferential finger flow. The occurrence of nonequilibrium was related to water flow across numerous beds of varying initial water content and unsaturated conductivity. In contrast, horizontal cores with continuous beds parallel to the direction of flow were conducive to unsaturated flow without the development of PNE. This suggests the propensity for the rapid lateral spreading of contaminants in semi-arid regimes, but lithologic discontinuities present in the media could disrupt lateral flow, thus resulting in local-scale perching and vertical preferential finger flow. Such local-scale nonequilibrium processes may result in a complicated distribution of contaminants in the field that may be difficult to predict using conventional transport models. 
Multiple nonreactive tracer techniques demonstrated that the development and persistence of immobile water could act as a short-term sink and long-term source of potential contaminants to preferential flowpaths in both humid regime structured soils and semi-arid regime laminated sediments.

\section{Acknowledgements}

This research was sponsored by the US Department of Energy, Office of Environmental Management, Environmental Management and Science Program. The authors appreciate the efforts of Mark Gilbertson, the contract officer for the Department of Energy who supported this work. G.V. Wilson, L. Papelis, M.N. Pace, and S.C. Brooks are acknowledged for improvements to the manuscript as a result of their reviews. B. Hu and Z. Yu are acknowledged for their efforts in compiling this issue. Oak Ridge National Laboratory is managed by the University of Tennessee-Battelle, LLC, under contract DE-AC0500OR22725 with the US Department of Energy.

\section{References}

Akratanakul, S., Boersma, L., Klock, G.O., 1983. Sorption processes in soils as influenced by pore water velocity, 2 . Experimental results. Soil Sci. 135 (6), 331-341.

Bauters, T.W.J., DiCarlo, D.A., Steenhuis, T.S., Parlange, J.-Y., 2000. Soil water content dependent wetting front characteristics in sands. J. Hydrol. 231-232, 244-254.

Becker, M.W., Shapiro, A.M., 2000. Tracer transport in fractured crystalline rock: evidence of nondiffusive breakthrough tailing. Water Resour. Res. 36 (7), 1677-1686.

Bjornstad, B.N., 1990. Geohydrology of the 218-W-5 burial ground, 200-west area, Hanford site. PNNL-7336, Pacific Northwest National Laboratory, Richland, WA.

Bond, W.J., Wierenga, P.J., 1990. Immobile water during solute transport in unsaturated sand columns. Water Resour. Res. 26 (10), 2475-2481.

Bowman, R.S., 1984. Evaluation of some new tracers for soil water studies. Soil Sci. Soc. Am. J. 48, 987-993.

Bowman, R.S., Gibbens, J.F., 1992. Difluorobenzoates as nonreactive tracers in soil and groundwater. Ground Water 30, 8-14.

Connelly, M.P., Ford, B.H., Borghese, J.U., 1992. Hydrogeologic model for the 200 West groundwater area. WHC-SD-EN-T-014 (Rev. 0), Westinghouse Hanford Company, Richland, WA.

DiCarlo, D.A., Bauters, T.W.J., Darnault, J.G., Steenhuis, T.S., Parlange, J.-Y., 1999. Lateral expansion of preferential flow paths in sands. Water Resour. Res. 35 (2), 427-434.
Diment, G.A., Watson, K.K., 1985. Stability analysis of water movement in unsaturated porous materials 3. Experimental studies. Water Resour. Res. 21 (7), 979-984.

Dreier, R.B., Solomon, D.K., Beaudoin, C.M., 1987. Fracture characterization in the unsaturated zone of a shallow land burial facility, Flow and Transport through Fractured Rock. Monograph No. 42, American Geophysical Union, Washington, DC, pp. $51-59$.

Gaber, H.M., Inskeep, W.P., Comfort, S.D., Wraith, J.M., 1995. Nonequilibrium transport of atrazine through large intact soil cores. Soil Sci. Soc. Am. J. 59, 60-67.

Gamerdinger, A.P., Kaplan, D.I., 2000. Application of continuousflow centrifugation method for solute transport in disturbed, unsaturated sediments and illustration of mobile-immobile water. Water Resour. Res. 36 (7), 1747-1755.

Glass, R.J., Steenhuis, T.S., Parlange, J.-Y., 1988. Wetting front instability as a rapid and far-reaching hydrologic process in the vadose zone. J. Contam. Hydrol. 3, 207-226.

Glass, R.J., Steenhuis, T.S., Parlange, J.-Y., 1989. Mechanism for finger persistence in homogenous, unsaturated, porous media: theory and verification. Soil Sci. 148, 60-70.

Good, N.E., Winget, G.D., Winter, W., Connolly, T.N., Izawa, S., Singh, R.M.M., 1966. Hydrogen ion buffers for biological research. Biochemistry 5, 467-477.

Hatcher, R.D., Jr., Lemiszki, P.J., Dreier, R.B., Ketelle, R.H., Lee, R.R., Leitzke, D.A., McMaster, W.M., Foreman, J.L., Lee, S.Y., 1992. Status report on the geology of the Oak Ridge Reservation. Oak Ridge National Laboratory, Oak Ridge, TN, ORNL/TM-12074, 244 pp.

Hayduk, W., Laudie, H., 1974. Prediction of diffusion coefficients for nonelectrolytes in dilute aqueous solutions. AIChE J. 20, 611-615.

Hillel, D., Baker, R.S., 1988. A descriptive theory of fingering during infiltration into layered soils. Soil Sci. 146, 51-56.

$\mathrm{Hu}$, Q., Brusseau, M.L., 1994. The effect of solute size on diffusivedispersive transport in porous media. J. Hydrol. 158, 305-317.

Hu, Q., Brusseau, M.L., 1995. Effect of solute size in transport in structured, porous media. Water Resour. Res. 31 (7), $1637-1646$.

James, R.V., Rubin, J., 1986. Transport of chloride ion in a waterunsaturated soil exhibiting anion exclusion. Soil Sci. Soc. Am. J. $50,1142-1149$.

Jardine, P.M., Taylor, D.L., 1995. Kinetics and mechanisms of Co(II)EDTA oxidation by pyrolusite. Geochem. Cosmochim. Acta 59, 4193-4203.

Jardine, P.M., Wilson, G.V., Luxmoore, R.J., 1988. Modeling the transport of inorganic ions through undisturbed soil columns from two contrasting watersheds. Soil Sci. Soc. Am. J. 52, $1252-1259$

Jardine, P.M., Jacobs, G.K., Wilson, G.V., 1993. Unsaturated transport processes in undisturbed heterogeneous porous media: I. Inorganic contaminants. Soil Sci. Soc. Am. J. 57, 945-953.

Jardine, P.M., O'Brien, R., Wilson, G.V., Gwo, J.-P., 1998. Experimental techniques for confirming and quantifying physical nonequilibrium processes in soils. In: Selim, H.M., Ma, L. (Eds.), Physical Nonequilibrium in Soils: Modeling and Application, Ann Arbor, Chelsea, MI, pp. 243-271. 
Jardine, P.M., Wilson, G.V., Luxmoore, R.J., Gwo, J.-P., 2001. Conceptual model of vadose-zone transport in fractured weathered shales. In: Hsieh, P.A., (Ed.), Conceptual Models of Flow and Transport in the Fractured Vadose Zone, U. S. national Comittee for Rock Mechanic S. National Research Council. National Academy Press, Washington D. C., 87-114.

Klute, A., 1986. Water retention: laboratory methods. In: Klute, A., (Ed.), Methods of Soil Analysis, Part 1, Second ed, Agronomy Monograph No. 9, ASA and SSSA, Madison, WI, pp. 635-660.

Koch, S., Fluhler, H., 1993. Nonreactive solute transport with micropore diffusion in aggregated porous media determined by a flow-interruption method. J. Contam. Hydrol. 14, 39-54.

Langner, H.W., Gaber, H.M., Wraith, J.M., Huwe, B., Inskeep, W., 1999. Preferential flow through intact soil cores: effects of matric head. Soil Sci. Soc. Am. J. 63, 1591-1598.

Lindsey, K.A., Gaylord, D.R., 1990. Lithofacies and sedimentology of the Miocene-Pliocene Ringold Formation, Hanford site, south-central Washington. Northwest Sci. 64 (3), $165-180$.

Looney, B.B., Falta, R.W., 2000. The vadose zone: what it is, how it works, and why it matters. In: Looney, B.B., Falta, R.W. (Eds.), Vadose Zone Science and Technology Solutions, Batelle Press, Columbus, OH, pp. 5-16.

Luxmoore, R.J., 1981. Micro-, meso-, and macroporosity of soil. Soil Sci. Soc. Am. J. 45, 671

Mayes, M.A., Pace, M.N., Jardine, P.M., 2003. Lithologic controls on the development of unstable flow in undisturbed cores of variably saturated laminated silts and sands. In preparation.

McCarthy, J.F., Howard, K.M., McKay, L.D., 2000. Effect of pH on sorption and transport of fluorobenzoic acid ground water tracers. J. Environ. Qual. 29 (6), 1806-1813.

Moline, G.R., Ketcham, R., Toedte, R.J., 2001. Geologic controls on fracture-matrix exchange processes in fractured porous media: results from a multi-tracer investigation. Fractured Rock 2001 Conference, Toronto, ON, Canada, March 25-28.

Mualem, Y., 1976. A new model for predicting the hydraulic conductivity of unsaturated porous media. Water Resour. Res. 12 (3), 513-522.

Olsen, C.R., Lowry, P.D., Lee, S.Y., Larsen, I.L., Cutshall, N.H., 1986. Geochemical and environmental processes affecting radionuclide migration from a formerly used seepage trench. Geochim. Cosmochim. Acta 50, 593-607.

Padilla, I.Y., Yeh, T.-C., Conklin, M.H., 1999. The effect of water content on solute transport in unsaturated porous media. Water Resour. Res. 35 (11), 3303-3313.

Parker, J.C., van Genuchten, M.Th., 1984. Determining transport parameters from laboratory and field tracer experiments. Va. Agric. Exp. Stn., Blacksburg, VA, Bull. No. 84-3, 97 pp.

Porro, I., Wierenga, P.J., 1993. Transient and steady-state solute transport through a large unsaturated soil column. Ground Water 31 (2), 193-200.

Reedy, O.C., Jardine, P.M., Wilson, G.V., Selim, H.M., 1996. Quantifying the diffusive mass transfer of nonreactive solutes in columns of fractured saprolite using flow interruption. Soil Sci. Soc. Am. J. 60, 1376-1384.

Ritsema, C.J., Dekker, L.W., Hendrickx, J.M.H., Hamminga, W., 1993. Preferential flow mechanism in a water repellent sandy soil. Water Resour. Res. 29 (7), 2183-2193.

Ritsema, C.J., Dekker, L.W., Nieber, J.L., Steenhuis, T.S., 1998. Modeling and field evidence of finger formation and finger recurrence in a water repellent sandy soil. Water Resour. Res. 34 (4), 555-567.

Roh, Y., Mayes, M.A., Pace, M.N., Choi, S.K., Chorover, J., Jardine, P.M., 2003. Geochemical and mineralogical characterization of sediments at the Hanford site, Washington. Soil Sci. Soc. Am. J. in preparation.

Rothschild, E.R., Huff, D.D., Spalding, B.P., Lee, S.Y., Clapp, R.B., Lietzke, D.A., Stansfield, R.G., Farrow, N.D., Farmer, C.D., Munro, I.L., 1984. Characterization of soils at proposed solid waste storage area (SWSA) 7. Oak Ridge National Laboratory, Oak Ridge, TN, ORNL/TM-9326, 151 pp.

Seyfried, M.S., Rao, P.S.C., 1987. Solute transport in undisturbed columns of an aggregated tropical soil: preferential flow effects. Soil Sci. Soc. Am. J. 51, 1434-1444.

Sililo, O.T.N., Tellam, J.H., 2000. Fingering in unsaturated zone flow: a qualitative review with laboratory experiments on heterogeneous systems. Ground Water 38 (6), 864-871.

Smettem, K.R.J., 1984. Soil-water residence time and solute uptake 3. Mass transfer under simulated rainfall conditions in undisturbed soil cores. J. Hydrol. 67, 235-248.

Tokunaga, T.K., Wan, J., 1997. Water film flow along fracture surfaces of porous rock. Water Resour. Res. 33 (6), 1287-1295.

Tokunaga, T.K., Wan, J., Sutton, S.R., 2000. Transient film flow on rough fracture surfaces. Water Resour. Res. 36 (7), 1737-1746.

Tucker, W.A., Nelken, L.H., 1982. Diffusion coefficients in air and water. In: Lyman, W.J., Reehl, W.F., Rosenblatt, D.H. (Eds.), Handbook of Chemical Property Estimation Methods: Environmental Behavior of Organic Compounds, McGraw-Hill, New York, pp. 17-20, Chapter 17.

van Genuchten, M.Th., 1980. A closed-form equation for predicting the hydraulic conductivity of unsaturated soils. Soil Sci. Soc. Am. J. 44, 892-898.

van Genuchten, M.Th., Leij, F.J., Yates, S.R., 1991. The RETC code for quantifying functions of unsaturated soils. EPA/600/2$91 / 065$, p. 85.

Wilson, G.V., Luxmoore, R.J., 1988. Infiltration, macroporosity, and mesoporosity distributions on two forested watersheds. Soil Sci. Soc. Am. J. 53, 329-335.

Wilson, G.V., Jardine, P.M., Gwo, J.-P., 1992. Modeling the hydraulic properties of a multiregion soil. Soil Sci. Soc. Am. J. 56, $1731-1737$

Young, M.H., Wierenga, P.J., Warrick, A.W., Hofmann, L.L., Musil, S.A., 1999. Variability of wetting front velocities during a field-scale infiltration experiment. Water Resour. Res. 35 (10), 3079-3087. 